\title{
Land use effects on leaf litter breakdown in low-order streams draining a rapidly developing tropical watershed in Puerto Rico
}

\author{
Pedro J. Torres ${ }^{1} \&$ Alonso Ramírez ${ }^{2}$ \\ 1. Odum School of Ecology, University of Georgia, Athens, GA, USA; pjtorres@uga.edu \\ 2. Department of Environmental Sciences, University of Puerto Rico, San Juan, PR, USA; aramirez@ramirezlab.net
}

Received 12-XII-2013. Corrected 20-I-2014. Accepted 13-II-2014.

\begin{abstract}
Land use has an important role influencing stream ecosystem processes, such as leaf litter breakdown. Here, we assessed rates of leaf litter breakdown in low-order tropical streams draining forest, agriculture, and urban land uses in Puerto Rico. To measure leaf breakdown rates, we placed litter bags made of coarse mesh in nine streams, three for each land use type. At each stream, we measured changes in leaf mass over time, leaf breakdown rates, macroinvertebrate assemblages, and stream physicochemistry. Streams differed in their water physicochemistry, with urban streams showing high values for most variables. Stream physical habitat was evaluated using a visual assessment protocol, which indicated that agricultural and urban streams were more degraded than forested streams. Leaf breakdown rates were fast in all streams (k values ranging 0.0060.024). Breakdown rates were significantly related to the physical conditions of the stream channel (e.g., visual protocol scores), with fastest rates in forested streams. Invertebrates colonizing leaves were mainly mayflies (Leptophlebiidae, Baetidae, and Caenidae), dipterans (Chironomidae), caddisflies (Polycentropodidae), and beetles (Elmidae and Gyrinidae). Our streams lacked large decapod populations, contrasting with other Puerto Rican streams. We found little evidence for an insect effect on leaf breakdown. Results suggest that land use is an important factor affecting leaf litter processing in streams. In contrast to studies in temperate regions, we found little evidence for a positive nutrient related effect of agricultural land use on decomposition rates. Changes in the physical characteristics of streams appear to be the main drivers behind observed decomposition patterns. Rev. Biol. Trop. 62 (Suppl. 2): 129-142. Epub 2014 April 01.
\end{abstract}

Key words: tropical streams, land use, detritivores, human impacts, decay rates, Puerto Rico.

The importance of the connection between streams and their watersheds via the movement of water and materials is well established in stream ecology (Hynes, 1975; Allan, 2004). Land-use and other anthropogenic activities in the watershed are known to directly affect stream physical and chemical parameters, thus altering the way in which ecosystem processes occur. Riparian zones play a fundamental role in buffering or constraining some of those effects. These zones influence water temperature and light availability by providing direct shading, they are also a major source of organic matter to stream food webs, and their presence is important to maintain the natural complexity of stream ecosystems (Sweeney et al., 2004;
Richardson, Zhang \& Marczak, 2010). Among the many connections between terrestrial and aquatic ecosystems, the movement of leaf litter from riparian vegetation to stream ecosystems and its importance in providing energy for stream food webs has been extensively studied (Webster \& Benfield, 1986; Wallace, Eggert, Meyer \& Webster, 1997). Human activities that reduce riparian vegetation are known to severely alter this terrestrial - aquatic linkage and therefore stream biodiversity and function. Removal of riparian vegetation can change the trophic basis of stream food webs from heterotrophic (based on leaf material) to autotrophic (based on algal production) and this shift can result in a complete change in the stream 
consumer community structure (Wallace \& Gurtz, 1986; Dudgeon, 1994; Benstead, Douglas \& Pringle, 2003).

Leaf litter entering streams from the riparian zone is a particularly important energy source for small headwater streams. A diverse array of aquatic organisms is adapted to consume leaf material in streams. In general, aquatic fungi are the initial colonizers on leaf substrates and responsible of starting the breakdown process, leaves colonized by fungi are more palatable to aquatic invertebrates that consume them and accelerate the process. In temperate streams, insect shredders (e.g., tipulid dipterans, stoneflies) consume and convert leaf material into fine particles that are transported downstream, or consumed by other organisms (Hieber \& Gessner, 2002). In warm-water tropical streams, microbial activity potentially plays a larger role in making leaf material a palatable resource not only to shredders, but also to omnivorous consumers, in particular insect collectors, omnivorous decapods (e.g., crabs and shrimps), and fishes (Crowl, McDowell, Covich \& Johnson, 2001; Encalada, Calles, Ferreira, Canhoto \& Graça, 2010; March, Benstead, Pringle \& Scatena, 2001; Rosemond, Pringle, Ramírez \& Paul, 2001; Bobeldyk \& Ramírez, 2007). Therefore, in both tropical and temperate streams a great number of aquatic organisms can be potentially connected to leaf detritus entering streams (Wallace et al., 1997; Benstead et al., 2003). Leaf breakdown is also controlled by abiotic factors, such as water flow and sediment scouring (Webster et al., 1999).

With human activities changing the landscape and altering linkages between terrestrial and aquatic ecosystems, it is important to understand how stream ecosystems respond to land use change. This knowledge is critical to understand human impacts on streams if we are to design conservation and restoration programs. Assessment of the relation between leaf litter breakdown in the stream and land use on the watershed provides an opportunity to understand how streams are impacted (Young, Matthaei \& Townsend, 2008). Rates of leaf breakdown are the result of biotic and abiotic factors and land uses can alter both factors (Gessner, Chauvet \& Dobson, 1999). Land uses that increase water nutrient levels can potentially enhance breakdown due to positive nutrient effects on microbial activity (Robinson \& Gessner, 2000). In contrast, land uses that alter stream channels and increase sedimentation could bury leaf material slowing their breakdown or increase scouring and accelerate breakdown (Paul \& Meyer, 2001).

Our understanding of the effects of land use on leaf breakdown in streams is limited, even in temperate zones (Paul, Meyer \& Couch, 2006). Rapid rates of land use conversion from forest to agriculture are a common feature of tropical regions. However, in certain parts of the tropics, urbanization and urban sprawl are becoming the dominant land use change. In Puerto Rico, for example, forest and agricultural lands are been rapidly converted into urban areas as industrialization increases on the island (Grau et al., 2003). This study is part of our ongoing efforts to understand how land use affects tropical stream ecosystems in Puerto Rico. Our main goal is to assess the relation between land use and leaf litter breakdown rates in low order tropical streams that drain a range of land uses from forest, agricultural, to urban. Our study has two main objectives, to: (1) assess the overall effect of land use on leaf breakdown rates, and (2) assess the relative importance of biotic and abiotic factors in controlling leaf breakdown.

\section{MATERIALS AND METHODS}

Study sites: Study streams were tributaries within the Turabo River watershed near the central region of Puerto Rico (Fig. 1). The Turabo River is part of the Grande de Loiza River watershed, the largest drainage in northeast Puerto Rico. Turabo is a rapidly developing watershed in close proximity of major urban centers. We selected nine low-order streams $\left(1^{\text {st }}-3^{\text {rd }}\right.$ order $)$, three for each major land use: forest, agriculture (mostly pastures), and urban. Forested streams were draining 


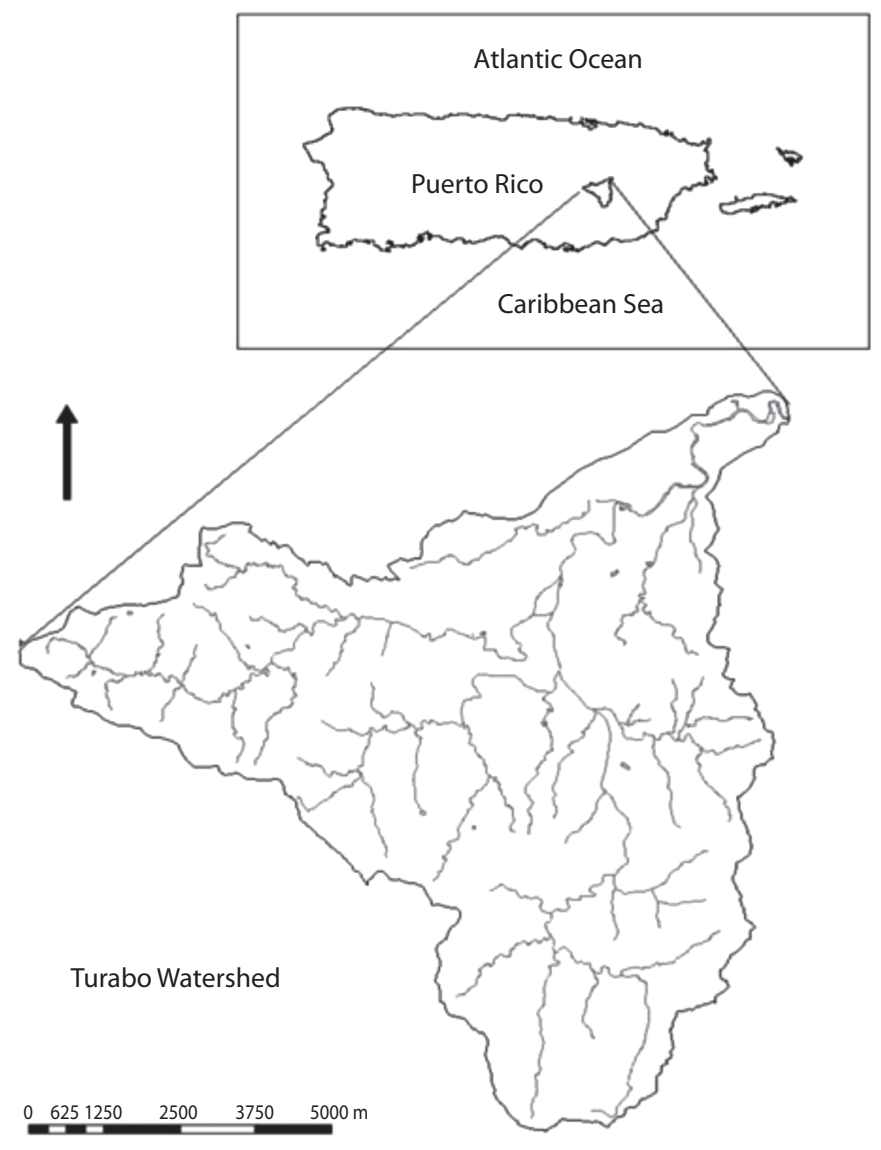

Fig. 1. Turabo River watershed in central Puerto Rico. The watershed drains toward the north-east corner, where it joins the Grande de Loiza watershed.

secondary forest after agricultural abandonment in the 1940s, canopy cover was dense $(\sim 90 \%)$ and the benthic substrate was rocky, mainly composed of cobbles and pebbles with boulders in some areas. Leaf litter was abundant and algal growth was not evident on rocks. Agricultural streams were draining low intensity cattle pastures, had scatter riparian vegetation, canopy cover was open $(\sim 50 \%)$, and the benthic substrate was composed mainly of rocks and sand. Most rocks had thick algal mats suggesting certain degree of nutrient enrichment. Urban streams were located in urban centers and had some riparian vegetation with a dense canopy cover at some sites ( $60-80 \%)$. Urban stream channels were straightened with rip-rap, but not channelized with concrete, and the benthic substrate was dominated by sand and cobbles in riffles and algal mats and leaf litter were evident.

The Turabo River watershed does not have the characteristic large native shrimp and fish assemblages described for other Puerto Rican streams (e.g., Pringle, Hemphill, McDowell, Bednarek \& March, 1999). This watershed is upstream from the Carraizo reservoir and dam, one of the major water supply sources to the metropolitan area of San Juan. The dam is probably the main reason for the lack of native shrimp and fish fauna in our study streams, as all of them have migratory life cycles and major dams can extirpate them from upstream 
reaches (Greathouse, Pringle, McDowell \& Holmquist, 2006; March et al., 2003). We only observed a few $(<3)$ atyid shrimps in one of the forested sites, possibly a relic population (Kwak, Cooney \& Brown, 2007).

Physicochemical parameters and habitat assessment: Stream physical and chemical characteristics were measured once during the experiment. Conductivity, $\mathrm{pH}$, temperature, total dissolved solids, ammonia $\left(\mathrm{NH}_{4}\right)$, and nitrate $\left(\mathrm{NO}_{3}\right)$ were determined using a multiparameter sonde (HACH Hydrolab DS-5). Stream physical conditions were characterized using the Stream Visual Assessment Protocol as modified for Hawaii (HSVAP) by the US Department of Agriculture (USDA, 2001). This protocol assesses the condition of the stream channel by visual evaluation of certain features (e.g., channelization, riparian vegetation, instream habitat, among others) and scores a test site from low to high habitat quality. The HSVAP has proven useful at identifying impacted streams in Puerto Rico and is able to assess different degrees of impact to streams (de Jesús-Crespo \& Ramírez, 2011).

Experimental design: Breakdown rates for Cecropia schreberiana were determined at each study stream using leaf bags constructed with coarse mesh screen $(2.5 \mathrm{~mm}$ mesh size) and anchoring the bags to the stream bottom. Cecropia is a common pioneer tree species in Puerto Rico that grows in open areas, forest gaps, and along stream banks (Brokaw, 1998). Freshly fallen leaves were collected and air dried for $24 \mathrm{hrs}$. Cecropia has large leaves that were cut to have smaller sections to make the leaf packs. Approximately $5 \mathrm{~g}$ of air-dried leaves were placed inside each bag. Initial weight of leaf packs was corrected by oven drying $\left(70^{\circ} \mathrm{C}\right.$ for $\left.24 \mathrm{hrs}\right)$ six leaf packs that were transported but not placed in the stream.

Groups of leaves were placed in three pools within a $50 \mathrm{~m}$ reach at each study stream. Pools were chosen to have low $(<0.01 \mathrm{~m} / \mathrm{s}$; using a Swoffer flow meter) and similar depth $(<40 \mathrm{~cm})$. One leaf pack was randomly collected from each pool on days $14,28,47$, and 65 . Leaf packs were removed from each pool using a $250 \mu \mathrm{m}$ net to catch any litter fragments and invertebrates. Samples were transported to the laboratory and processed within $24 \mathrm{hrs}$ after collection. Leaves were rinsed into a $250 \mu \mathrm{m}$ sieve to remove sediments and invertebrates and oven dried at $70^{\circ} \mathrm{C}$ for $24 \mathrm{hrs}$. A sub-sample of ground leaves was burned at $500^{\circ} \mathrm{C}$ for one hour to estimate ash free dry mass (AFDM). Another subsample was used to obtain carbon and nitrogen contents of the leaves at day 47 . All invertebrates collected from leaf packs were preserved in $80 \%$ ethanol and identified to family level using a dissecting microscope (10X).

Statistical analyses: Principal component analysis (PCA) was used to assess differences among streams in terms of water physicochemistry and to obtain a single composite score for each stream to relate it to breakdown rates. PCA analysis was run in PC-ORD 4.25 (McCune \& Mefford, 1999). Leaf litter breakdown rates (per day) were calculated using the exponential decay model $M_{t}=M_{o} e^{-k t}$ where $M_{t}$ is the initial dry mass and $\mathrm{M}_{\mathrm{o}}$ is the final dry mass (Benfield, 2007). The breakdown rate coefficients (expressed as k) were calculated for each stream as the slope of the line fitting the percent AFDM remaining (log-transformed) versus time (days).

Relationships between independent variables and breakdown rates were assessed using linear regression analyses and stepwise multiple using JMP (version 4.04; SAS Institute, Cary, North Carolina). For stepwise multiple regression, we used the forward model with a probability to enter the model of 0.25 and to leave the model of 0.10 (i.e., default setting in JMP). All variables were tested for normality and log-transformed $\left(\log _{10}[\mathrm{x}+1]\right)$ if required.

\section{RESULTS}

Water physicochemistry and stream visual evaluation: Water characteristics differed among streams, with urban streams showing the highest values for all physicochemical 
variables (Table 1). In contrast, minimum values were recorded at either forested or agricultural streams (Table 1). PCA ordination explained $92 \%$ of the variance among streams (Fig. 2). Axis 1 explained $52.2 \%$ of the variance and separated sites along a conductivity and TDS gradient. Axis 2 explained an additional $40.6 \%$ and formed a gradient mainly related to differences in water $\mathrm{pH}$ and $\mathrm{NO}_{3}$ among urban streams (Fig. 2).
Visual evaluation of the streams using HSVAP showed a similar trend to the physicochemical variables. Forested streams received scores above 1.5 indicating high physical habitat quality; agricultural streams received scores between 1.3 and 1.4 rating them as of medium habitat quality, and urban streams received scores $<1.0$ and indicative of low quality (Fig. 3). Analysis of variance indicated that variation among forested and agricultural

TABLE 1

Stream water physicochemical characteristics for all study streams in the Turabo River watershed, Puerto Rico. Measurements were taken once during the experiment

\begin{tabular}{lcccccc}
\multicolumn{1}{c}{ Stream } & $\begin{array}{c}\text { Temperature } \\
\left({ }^{\circ} \mathrm{C}\right)\end{array}$ & $\begin{array}{c}\text { Conductivity } \\
(\mu \mathrm{S})\end{array}$ & $\begin{array}{c}\text { Total Suspended } \\
\text { Solids }(\mathrm{mg} / \mathrm{L})\end{array}$ & $\mathrm{pH}$ & $\begin{array}{c}\mathrm{NH}_{4} \\
(\mathrm{mg} / \mathrm{L})\end{array}$ & $\begin{array}{c}\mathrm{NO}_{3} \\
(\mathrm{mg} / \mathrm{L})\end{array}$ \\
Forested-1 & 24.22 & 181.10 & 0.12 & 7.57 & 0.15 & 0.34 \\
Forested-2 & 23.19 & 198.50 & 0.13 & 7.48 & 0.13 & 0.47 \\
Forested-3 & 24.12 & 185.20 & 0.12 & 7.55 & 0.14 & 0.43 \\
Agricultural-1 & 25.88 & 147.30 & 0.09 & 7.35 & 0.16 & 0.97 \\
Agricultural-2 & 26.99 & 187.70 & 0.12 & 7.54 & 0.12 & 0.63 \\
Agricultural-3 & 25.05 & 117.20 & 0.08 & 7.33 & 0.12 & 0.80 \\
Urban-1 & 27.61 & 372.70 & 0.24 & 7.10 & 0.29 & 0.52 \\
Urban-2 & 31.49 & 267.20 & 0.17 & 8.41 & 0.13 & 3.24 \\
Urban-3 & 26.19 & 358.30 & 0.23 & 7.43 & 0.22 & 1.44 \\
\hline
\end{tabular}

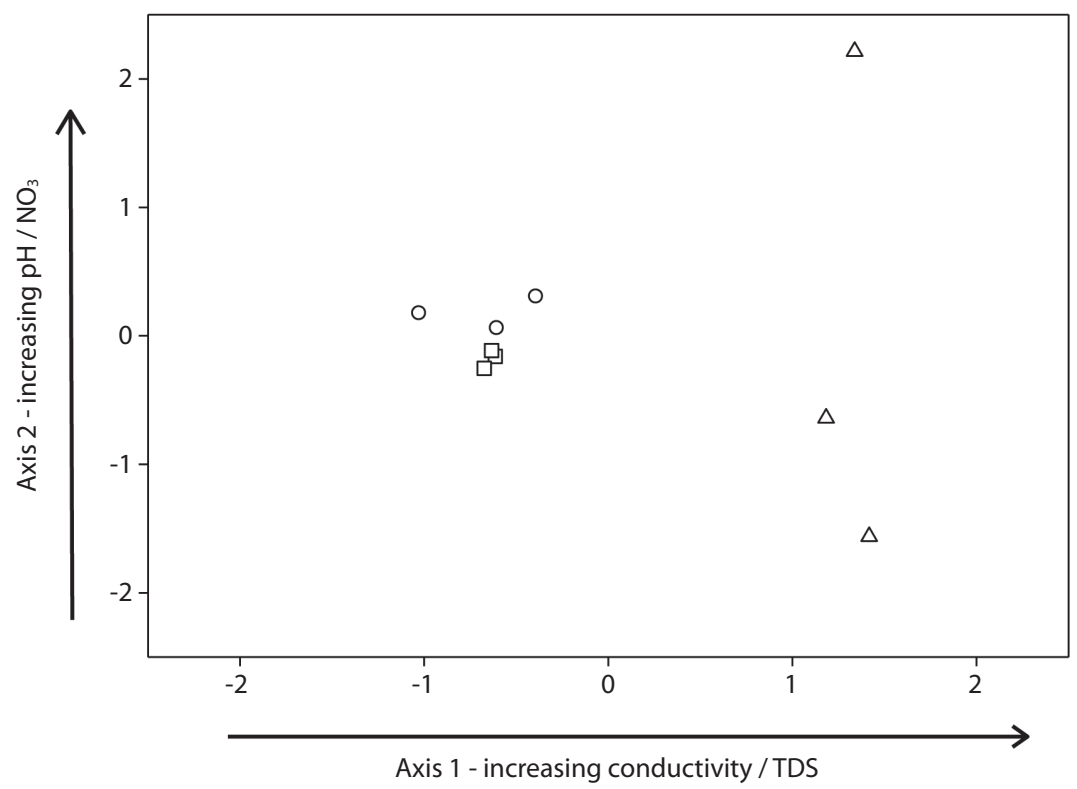

Fig. 2. Ordination analysis of stream physicochemical variables. Symbols as follow: squares represent forested sites, circles agricultural sites, and triangles urban sites. 
streams was similar and only urban sites were significantly different in terms of the physical evaluation of their channels (ANOVA, land use: $F=17.90, d f=2, p<0.01$; Table 2).

Leaf litter breakdown: Rates were calculated for all streams, except for one agricultural site where we lost some leaf bags and were unable to calculate breakdown rates (Table 3). Leaf breakdown rates were fast in all streams, ranging from 0.006 day $^{-1}$ in an urban stream to 0.024 day $^{-1}$ in a forested stream (Table 3). Percent AFDM remaining at the last day of the experiment (day 65) ranged from $17 \%$ at a forested stream to $53 \%$ in an urban stream. Percent carbon of leaves at day 47 of the experiment ranged from 40-46\%, nitrogen from 1.5$1.9 \%$ and $\mathrm{C}: \mathrm{N}$ ratios from 20-27 (Table 4).

Streams formed a gradient in ordination space, rather than discrete groups (Fig. 2). Thus, we used PCA axis 1 scores as indicators of stream physicochemistry and scores from the visual assessment protocol as an index of stream physical condition. Percent AFDM remaining was significantly and negatively related to visual scores while leaf breakdown rates and leaf carbon content were also significantly related but positively (Table 5, Fig. 4). PCA axis 1 entered some of the models, but was not significantly related to any of the
TABLE 2

Comparison of stream physicochemical variables among land use types at the Turabo River watershed, using one-way ANOVA

\begin{tabular}{lcccc}
\multicolumn{1}{r}{ Variable } & $\mathrm{F}$ & df & P-value & Comparison \\
Temperature & 5.38 & 2 & 0.04 & $\mathrm{U}>\mathrm{A}>\mathrm{F}$ \\
Conductivity & 18.04 & 2 & $<0.01$ & $\mathrm{U}>\mathrm{A}=\mathrm{F}$ \\
$\mathrm{TDS}$ & 18.50 & 2 & $<0.01$ & $\mathrm{U}>\mathrm{A}=\mathrm{F}$ \\
$\mathrm{pH}$ & 0.27 & 2 & 0.77 & $\mathrm{U}=\mathrm{A}=\mathrm{F}$ \\
$\mathrm{NH}_{4}$ & 2.43 & 2 & 0.16 & $\mathrm{U}=\mathrm{A}=\mathrm{F}$ \\
$\mathrm{NO}_{3}$ & 3.48 & 2 & 0.09 & $\mathrm{U}=\mathrm{A}=\mathrm{F}$ \\
\hline
\end{tabular}

Comparisons are based on Tuckey tests. U: urban, A: agricultural, F: forest.

TABLE 3

Decay coefficients for each study stream at the Turabo River watershed

\begin{tabular}{lcccc}
\multicolumn{1}{c}{ Stream } & $\mathrm{k}$ & $\mathrm{n}$ & $\mathrm{P}$ value & $\mathrm{r}^{2}$ \\
Forested-1 & 0.0155 & 4 & 0.0014 & 0.94 \\
Forested-2 & 0.0214 & 4 & 0.0001 & 0.88 \\
Forested-3 & 0.0245 & 4 & 0.0034 & 0.63 \\
Agricultural-1 & 0.0218 & 4 & 0.0042 & 0.77 \\
Agricultural-2 & 0.0132 & 4 & 0.0011 & 0.80 \\
Agricultural-3 & nd & nd & nd & nd \\
Urban-1 & 0.0063 & 4 & 0.0163 & 0.53 \\
Urban-2 & 0.0200 & 3 & 0.0006 & 0.87 \\
Urban-3 & 0.0145 & 4 & 0.0004 & 0.80 \\
\hline
\end{tabular}

$\mathrm{k}=$ decay rate, $\mathrm{n}=$ number of sampling dates, $\mathrm{p}$ - value and $\mathrm{r}^{2}$ are for the regression model used to calculate $\mathrm{k}$. nd $=$ no data.

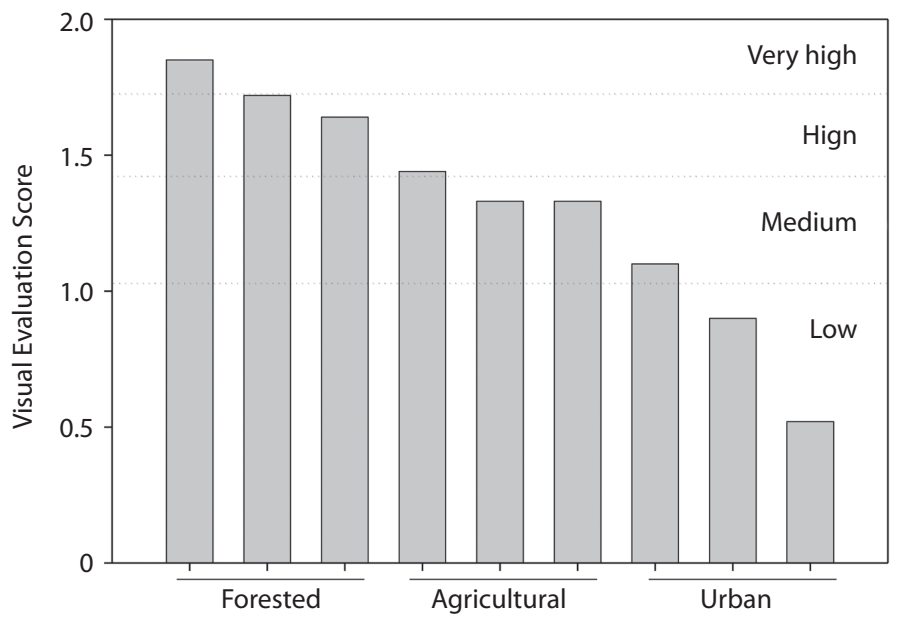

Fig. 3. Visual evaluation score results at each study stream obtained using the Hawaii Stream Visual Assessment Protocol (HSVAP). 
TABLE 4

Percent carbon, nitrogen and $\mathrm{C}: \mathrm{N}$ ratios for leave tissue at day 47 of the experiment in all study streams at the Turabo River watershed

\begin{tabular}{lccc}
\multicolumn{1}{c}{ Stream } & $\begin{array}{c}\text { \% Carbon } \\
\text { content }\end{array}$ & $\begin{array}{c}\text { \% Nitrogen } \\
\text { content }\end{array}$ & C:N ratios \\
Forested-1 & 45.91 & 1.98 & 23.20 \\
Forested-2 & 46.04 & 1.90 & 24.26 \\
Forested-3 & 44.59 & 1.73 & 25.93 \\
Agricultural-1 & 41.64 & 1.69 & 24.65 \\
Agricultural-2 & nd & nd & nd \\
Agricultural-3 & nd & nd & nd \\
Urban-1 & 41.64 & 1.50 & 27.68 \\
Urban-2 & 40.24 & 1.92 & 20.98 \\
Urban-3 & 41.17 & 1.77 & 23.21 \\
\hline
\end{tabular}

nd $=$ no data

TABLE 5

Stepwise multiple regression partial coefficients and significance $(*=\mathrm{P}<0.05)$ using the Hawaii Visual Assessment Protocol (HSVAP) and PCA Axis 1 to explain variables associated with leaf breakdown at the study streams

\begin{tabular}{lccc}
\multicolumn{1}{c}{ Variable } & \multicolumn{4}{c}{ Multiple Regression coefficient } \\
& HSVAP & PCA & Insects \\
AFDM remaining & $-0.75^{*}$ & 0.82 & - \\
Breakdown Rates & $0.50^{*}$ & - & - \\
C:N ratios & - & - & - \\
Carbon content & $0.65^{*}$ & - & - \\
Nitrogen content & 0.31 & - & - \\
\hline
\end{tabular}

variables (Table 5). Insect assemblages did not enter any of the multiple regression models.

Insect assemblages: Insects were dominated by the mayfly families Leptophlebiidae, Baetidae, and Caenidae. Dipterans were composed mostly of Chironomidae, caddisflies of Polycentropodidae, and beetles of Elmidae and Gyrinidae (Table 6). Total insect biomass was positively related to visual scores, both as biomass per bag and per g AFDM remaining (Table 7). In contrast, only insect abundance per bag was significantly related to PCA axis 1. Species richness was not related to either variable (Table 7).
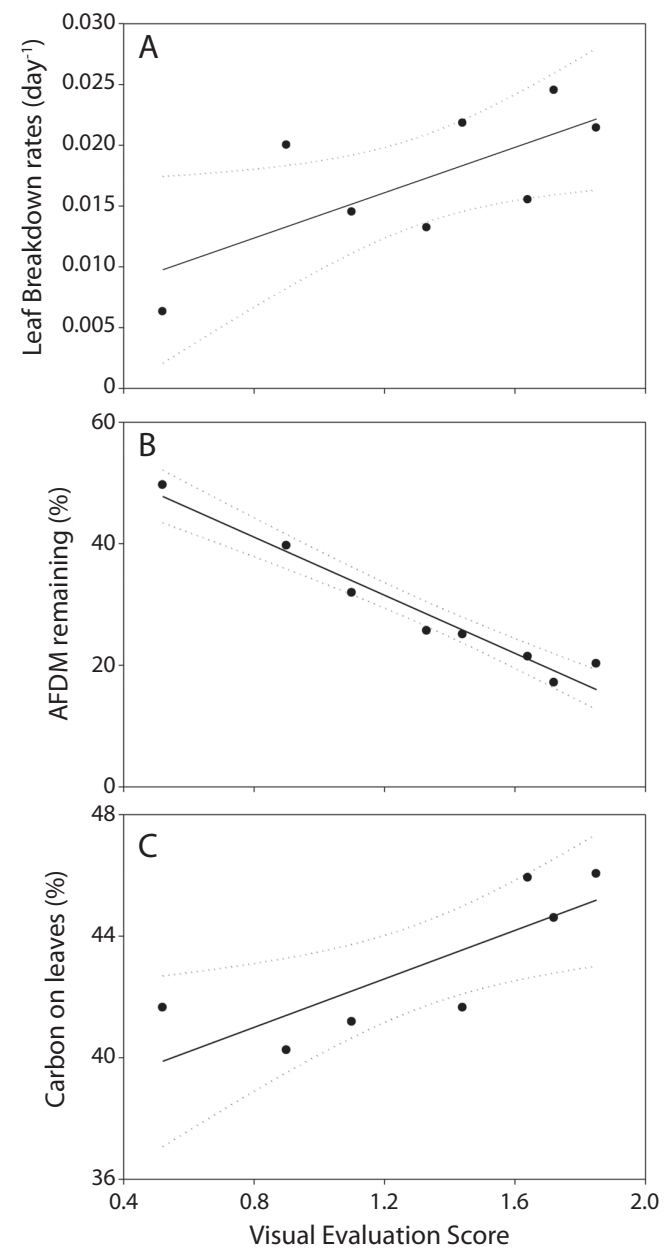

Fig. 4. Leaf breakdown rates (A), percent AFDM remaining (B), and \% leaf C (C) versus the stream visual assessment protocol scores.

Cluster analysis of insect assemblage composition based on their abundance showed that streams formed three major groups (Fig. 5). Forested streams mostly grouped together with only one stream, Forest-1, grouping with a mixture of other sites. Mayflies were the main group driving group formation. Leptophlebiidae and Baetidae were mainly present at forested and agricultural sites, while Caenidae were mainly present in agricultural and urban streams. Forest-1 was a stream with few mayflies in the samples. 
TABLE 6

Major insect groups colonizing leaf bags in streams at the Turabo River watershed.

Values are means of three streams per land use type

\begin{tabular}{|c|c|c|c|c|}
\hline & & Forested Bag & Agricultural Bag & Urban Bag \\
\hline \multicolumn{5}{|c|}{ Abundance (No. per bag) } \\
\hline \multirow[t]{3}{*}{ Ephemeroptera } & Leptophlebiidae & 19.67 & 4.67 & 0.50 \\
\hline & Baetidae & 0.00 & 1.83 & 0.00 \\
\hline & Caenidae & 0.50 & 2.17 & 4.33 \\
\hline Trichoptera & Polycentropodidae & 0.39 & 0.83 & 0.00 \\
\hline Odonata & Coenagrionidae & 0.17 & 0.50 & 0.00 \\
\hline \multirow[t]{2}{*}{ Coleoptera } & Gyrinidae & 0.33 & 0.33 & 0.00 \\
\hline & Elmidae & 0.94 & 0.00 & 0.67 \\
\hline \multirow[t]{2}{*}{ Diptera } & Chironomidae & 0.78 & 3.50 & 0.50 \\
\hline & Others & 0.11 & 0.00 & 0.50 \\
\hline \multicolumn{5}{|c|}{ Biomass (mg per bag) } \\
\hline \multirow[t]{3}{*}{ Ephemeroptera } & Leptophlebiidae & 7.39 & 2.12 & 0.15 \\
\hline & Baetidae & 0.00 & 2.85 & 0.00 \\
\hline & Caenidae & 0.09 & 0.57 & 0.71 \\
\hline Trichoptera & Polycentropodidae & 1.62 & 1.95 & 0.00 \\
\hline Odonata & Coenagrionidae & 1.15 & 0.03 & 0.00 \\
\hline \multirow[t]{2}{*}{ Coleoptera } & Gyrinidae & 7.42 & 9.27 & 0.00 \\
\hline & Elmidae & 0.29 & 0.00 & 0.18 \\
\hline \multirow[t]{2}{*}{ Diptera } & Chironomidae & 0.10 & 0.33 & 0.06 \\
\hline & Others & 0.03 & 0.00 & 0.07 \\
\hline
\end{tabular}

\section{DISCUSSION}

Understanding how stream ecosystems are affected by land use on the watershed is critical to assess their vulnerability to change. Land use impacts on stream ecosystems often occur via a combination of direct watershed effects and indirect effects via changes at the reach scale (Bernot et al., 2010). In urban and agricultural landscapes, watershed level impacts are associated with elevated nutrient concentrations and water conductivity in streams (Walsh et al., 2005), while reach level impacts are in the form of altered channel morphologies (Chin, 2006). Urban streams in the Turabo River watershed were clearly different from forest streams in their water physicochemistry and altered channel morphologies (e.g., impacted scores in the HSVAP). In contrast, agricultural streams had similar water physicochemistry to those of forested streams, possibly the result of the low intensity agricultural use, which
TABLE 7

Stepwise multiple regression partial coefficients and significance $(*=\mathrm{P}<0.05)$ using the Hawaii Visual Assessment Protocol (HSVAP) and PCA Axis 1 to explain patterns in insects colonizing leaf packs at the study streams.

\begin{tabular}{|c|c|c|}
\hline \multirow[t]{2}{*}{ Variable } & \multicolumn{2}{|c|}{$\begin{array}{l}\text { Multiple } \\
\text { Regression } \\
\text { coefficient }\end{array}$} \\
\hline & HSVAP & PCA \\
\hline Biomass per pack (mg / pack) & $0.49 *$ & - \\
\hline Biomass per gram (mg / g AFDM) & $0.58 *$ & - \\
\hline Abundance per pack (ind / pack) & -0.55 & $0.38^{*}$ \\
\hline Abundance per gram (ind / g AFDM) & - & 0.35 \\
\hline Species per pack (Spp / pack) & - & - \\
\hline Species per gram (Spp / g AFDM) & - & - \\
\hline
\end{tabular}

consisted mostly of scatter cattle ranching and small patches of row-crop farms. However, agricultural sites were clearly different in their channel characteristics and received scores of the HSVAP that indicated degradation. 


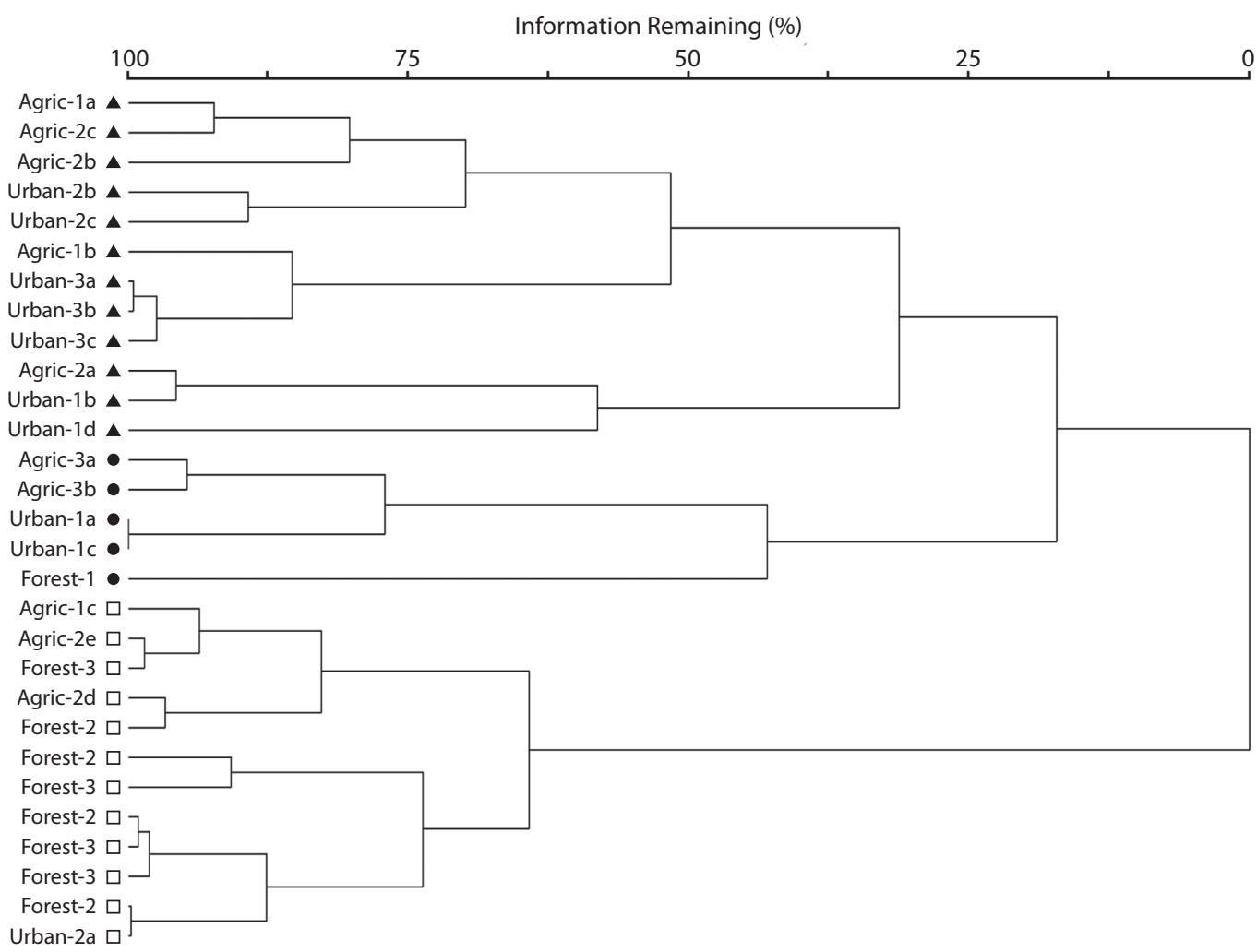

Fig. 5. Cluster analysis based on insect abundance in leaf packs for both treatments. The three main groups identified are represented by the different symbols, with triangles grouping mainly agricultural and urban sites and squares grouping forested sites. Circles grouped a mix of sites.

Breakdown rates in all our study streams can be considered fast $(\mathrm{k}>0.01)$ in relation to general leaf breakdown classifications (Peterson \& Cummins, 1974). Rates were also similar to those reported for Cecropia in other streams in Puerto Rico (March, Benstead, Pringle \& Ruebel, 2001), but slightly lower than rates reported for streams where shrimps are more abundant than at the Turabo River watershed (Wright \& Covich, 2005). Rapid rates of leaf breakdown highlight the importance of leaf litter as an energy source for tropical stream food webs (Boulton et al., 2008; Boyero, Ramírez, Dudgeon \& Pearson, 2009). Leaf litter accumulations tend to be conspicuous in small tropical forested streams, are present year round, and are habitats for a diversity of organisms (Ramírez, Paaby, Pringle \& Agüero, 1998). Traditional invertebrate shredders (e.g., Calamoceratidae, Trichoptera) are not as abundant in many tropical streams as in temperate streams and were almost absent at the Turabo River. It has been suggested that invertebrate shredders do not play an important role processing leaf litter in tropical streams (Ramírez \& Pringle, 1998; Dudgeon \& Wu, 1999). However, high microbial activity on leaves allows for non-shredding organisms (e.g., scraping mayflies, shrimps, snails) to consume leaf material, accelerating the process of decomposition (Bobeldyk \& Ramírez, 2007; Rosemond et al., 2001) and making this energy available to higher trophic levels (Ramírez \& Pringle, 2006). In addition, non-insect organisms such 
as decapods and fishes can consume large amounts of leaf material in tropical streams (Crowl et al., 2001; Rosemond et al., 2001).

Studies on the effects of land use on leaf litter breakdown in streams have highlighted the role that nutrients might play in increasing breakdown rates (Huryn, Butz Huryn, Arbuckle \& Tsomides, 2002; Paul et al., 2006). Agricultural and urban streams are often nutrient rich and leaf breakdown can be enhanced via positive effects on microbial communities. Fungi and bacteria that colonize leaves can obtain nutrients from the water column (Suberkropp \& Chauvet, 1995) and in doing so they condition leaf material, thus facilitating the decomposition process by making it more palatable to other invertebrate consumers. In contrast, we found little evidence for a positive nutrient related effect on leaf breakdown. All the agricultural activity near our study streams was low intensive and there was no evidence of commercial plantations or larger farms nearby. Therefore, nutrient loadings from these areas are not large enough to significantly increase concentrations in the stream and influence stream breakdown. Stream physical condition as a result of the different land uses was a better indicator of land use effects. Leaf breakdown was positively related to stream physical conditions. Streams with good physical conditions (e.g., high HSVAP scores) had the fastest breakdown rates. Although we only scored the overall physical characteristics, degraded streams often carry large sediment loads that could result in the burial of leaf material (Webster \& Benfield, 1986). Buried leaf packs limit the access to macroinvertebrates and microbes, resulting in slower decomposition rates.

Biotic controls on leaf breakdown in Puerto Rican streams have been mainly associated with the presence of shrimp assemblages that are able to consume leaf material (Crowl et al., 2001; March et al., 2001; Wright \& Covich, 2006). However, our study watershed lack the abundant shrimp assemblages natural of many streams in Puerto Rico, due to the presence of a large dam located downstream of all our study streams (Kwak et al., 2007). Large dams without any structure for animal movement between up- and down-stream (e.g., fish ladder) completely block the migratory pathways of amphidromous shrimps resulting in their extirpation from upstream reaches (Holmquist, Schmidt-Gengenbach \& Yoshioka, 1998). In the absence of shrimps, the only organisms that participated of leaf breakdown were microbes, insects, and snails. Most insects were from the families Leptophlebiidae (Ephemeroptera) and Chironomidae (Diptera). Although these families are not considered shredders, previous studies indicated that they consume leaves and also their feeding activities result increase breakdown rates (Rosemond et al., 2001). In addition, experimental shrimp exclusions at other locations in Puerto Rico have found insect abundance and biomass similar to the values we reported here. Bobeldyk \& Ramírez (2007) excluded shrimps and other macroconsumers using in-situ exclusions, the resulting insect assemblage composition and density was similar to the ones reported here (up to 30 individuals per pack $^{-1}$ ). Moreover, leaf breakdown rates in the work of Bobeldyk \& Ramírez (2007) decreased as a result of macroinvertebrate exclusion.

Macroinvertebrates are closely related to the environments they live in and assemblage composition is often very different in streams draining different land uses (Sponseller, Benfield \& Valett, 2001; Suga \& Tanaka, 2013). This characteristic response is the basis of many tools developed for stream biomonitoring (Bonada, Prat, Resh \& Statzner, 2006). In the Turabo River watershed, insect assemblage had similarities among streams draining different land uses. However, clear changes in dominance were observed in particular in mayfly composition. Leptophlebiidae was clearly a forest group and has been reported as dominant in other forest locations in Puerto Rico (Ramírez \& Hernández-Cruz, 2004). Leptophlebiidae nymphs are relatively large in comparison to other abundant insects at Turabo, thus the observed pattern of high biomass in forested streams is probably due to their dominance in forest environments. In agricultural and urban 
streams, Leptophlebiidae was replaced by Caenidae, a group that is adapted to environments with abundant sediments. Caenidae has a large and strong second pair of gills that protects the abdomen and covers the remaining gills, perhaps facilitating their colonization of impacted streams where sedimentation might exclude other mayfly groups. These two families show potential for use as indicators of habitat quality. In addition to changes in composition, insect abundance showed a relation with stream physicochemistry, indicating that disturbed urban streams had higher abundances than forest and pasture streams. Thus, land use affects both the composition and abundance of insects at Turabo River watershed.

Visual evaluation of stream conditions proved to be useful in assessing the physical environment and how it was related to land use. Although the protocol was adapted to Hawaii, it has been applied in other streams in Puerto Rico to successfully evaluate their physical condition (de Jesús-Crespo \& Ramírez, 2011). In the Turabo River watershed, both urban and agricultural streams had environmental conditions that departed from forested streams, with urban streams having more solutes, higher temperature and nutrient concentrations than agricultural and forested streams. However, water physicochemistry was similar between agricultural and forested streams. The emphasis that HSVAP places on the physical characteristics of the channel and the riparian vegetation was essential to notice the impact among the three land uses. Based on the HSVAP scores, streams formed a gradient from high to low quality that corresponded to the forested to urban land use. This gradient was clearly related with leaf breakdown rates, with a reduction in rates in streams with degraded conditions.

Land use plays a major role determining stream ecosystem characteristics and function (Sponseller et al., 2001; Silva-Junior, Moulton, Boëchat \& Gücker, 2014). In our study, forest, low intensity agriculture, and urban land uses resulted in clear changes in stream ecosystem function (i.e., organic matter processing) and biodiversity. Understanding how stream ecosystems respond to land use changes is critical for stream management and conservation. Forest cover in Puerto Rico has been increasing since the island economy changed from agricultural to industrial in the 1940s (Grau et al., 2003), and this change has a series of potential benefits for stream ecosystems (Aide \& Grau, 2004; Ramírez, Pringle \& Wantzen, 2008). However, parallel with industrialization, urban land use is also increasing on the island and today urban land cover comprises $16 \%$ of the island (Martinuzzi, Gould \& Ramos González, 2007). The Turabo River watershed is also becoming urbanized and new housing projects, hotels and golf courses are likely affecting the landscape. This scenario of forest and urbanization growth is also occurring in other tropical areas as countries strive to improve their economies and become industrialized (Montgomery, 2008). Given observed changes in stream physicochemistry, physical conditions, biodiversity, and ecosystem function, conservation and management efforts need to clearly understand how land use is impacting tropical stream ecosystems.

\section{ACKNOWLEDGMENTS}

We thank Sofía Burgos-Caraballo and Diana Martinó-Cardona for help with the initial logistics and set-up of the experiment. Hector M. Rosario provided help with sample collection. The manuscript was greatly improved by comments provided by Alan Covich and an anonymous reviewer. Funding was provided by the Luquillo LTER program (DEB-0620910).

\section{RESUMEN}

El uso de la tierra influye significativamente sobre los procesos en ecosistemas de riachuelo, como la descomposición de la hojarasca. En el presente estudio, se evaluaron las tasas de descomposición de la hojarasca en arroyos tropicales menores de zonas boscosa, agrícola y urbana en Puerto Rico. Para medir las tasas de descomposición se colocaron bolsas de malla gruesa en nueve riachuelos, tres para cada uno de los tipos de uso de tierra. Se midieron los cambios en la masa de hojarasca con el tiempo, las tasas de descomposición, la composición de macroinvertebrados y 
los aspectos físico-químicos del riachuelo. Los riachuelos mostraron diferencias en la fisico-química del agua: los riachuelos urbanos presentaron los valores más altos en casi todas las variables. Las características físicas del riachuelo fueron evaluadas utilizando un protocolo visual, el cual indica que los riachuelos urbanos y asociados a la agricultura están más degradados que los asociados a bosques. La tasa de descomposición de la hojarasca fue rápida en todos los riachuelos $(\mathrm{k}=0.006-0.024)$. La descomposición estuvo relacionada con las condiciones físicas del riachuelo, siendo más rápido en aquellos asociados al bosque. Los invertebrados que colonizaron las hojas fueron principalmente efemerópteros (Leptophlebiidae, Baetidae, and Caenidae), dípteros (Chironomidae), tricópteros (Polycentropodidae) y escarabajos (Elmidae and Gyrinidae). Contrario a lo encontrado en otros estudios, no hallamos decápodos. Hubo poca evidencia de que los insectos afecten la descomposición. Los resultados sugieren que el uso de la tierra es un factor importante que afecta el proceso de descomposición de la hojarasca en los riachuelos. Contrario a los estudios en zonas templadas, hallamos evidencia de una relación positiva de los nutrientes de tierra agrícola con las tasas de descomposición. Los cambios en las características físicas de los riachuelos parecen ser los factores principales en los patrones de descomposición.

Palabras clave: riachuelos tropicales, uso de tierra, detritivoros, impactos humanos, tasa de descomposición, Puerto Rico.

\section{REFERENCES}

Aide, T. M., \& Grau, H. R. (2004). Globalization, migration, and Latin American ecosystems. Science, 305, 1915-1916.

Allan, J. D. (2004). Landscapes and riverscapes: The influence of land use on river ecosystems. Annual Review of Ecology, Evolution, and Systematics, 35, 257-284.

Benfield, E. F. (2007). Decomposition of leaf material. In F. R. Hauer \& G. A. Lamberti (Eds.), Methods in stream ecology (pp. 711-720). New York: Academic Press.

Benstead, J. P., Douglas, M. M., \& Pringle, C. M. (2003). Relationships of stream invertebrate communities to deforestation in eastern Madagascar. Ecological Applications, 13, 1473-1490.

Bernot, M. J., Sobota, D. J., Hall, R. O., Mulholland, P. J., Dodds, W. K., Webster, J. R., Tank, J. L., Ashkenas, L. R., Cooper, L. W., Dahm, C. N., Gregory, S. V., Grimm, N. B., Hamilton, S. K., Johnson, S. L., McDowell, W. H., Meyer, J. L., Peterson, B., Poole, G. C., Valett, H. M., Arango, C., Beaulieu, J. J., Burgin, A. J., Crenshaw, C., Helton, A. M., Johnson, L., Merriam, J., Niederlehner, B. R., O’Brien, J. M.,
Potter, J. D., Sheibley, R. W., Thomas, S. M., \& Wilson, K. (2010). Inter-regional comparison of land-use effects on stream metabolism. Freshwater Biology, $55,1874-1890$.

Bobeldyk, A. M., \& Ramírez, A. (2007). Leaf breakdown in a tropical headwater stream (Puerto Rico): The role of freshwater shrimps and detritivorous insects. Journal of Freshwater Ecology, 22, 581-590.

Bonada, N., Prat, N., Resh, V. H., \& Statzner, B. (2006). Developments in aquatic insect biomonitoring: A comparative analysis of recent approaches. Annual Review Entomology, 51, 495-523.

Boulton, A. J., Boyero, L., Covich, A. P., Dobson, M., Lake, S., \& Pearson, R. G. (2008). Are tropical streams ecologically different from temperate streams? In D. Dudgeon. (Ed.) Tropical Stream Ecology. San Diego: Academic Press.

Boyero, L., Ramírez, A., Dudgeon, D., \& Pearson, R. G. (2009). Are tropical streams really different? Journal of the North American Benthological Society, 28, 397-403.

Brokaw, N. V. L. (1998). Cecropia schreberiana in the Luquillo Mountains in Puerto Rico. The Botanical Review, 64, 91-120.

Chin, A. (2006). Urban transformation of river landscapes in a global context. Geomorphology, 79, 460-487.

Crowl, T. A, McDowell, W. H., Covich, A. P., \& Johnson, S. L. (2001). Freshwater shrimp effects on detrital processing and nutrients in a tropical headwater stream. Ecology, 82, 775-783.

de Jesús-Crespo, R., \& Ramírez, A. (2011). The use of a Stream Visual Assessment Protocol to determine ecosystem integrity in an urban watershed in Puerto Rico. Physics and Chemistry of the Earth, 36, 560-566.

Dudgeon, D. (1994). The influence of riparian vegetation on macroinvertebrate community structure and functional-organization in 6 new-guinea streams. Hydrobiologia, 294, 65-85.

Dudgeon, D., \& Wu, K. K. Y. (1999). Leaf litter in a tropical stream: food or substrate for macroinvertebrates? Archive fur Hydrobiologie, 146, 65-82.

Encalada, A. C., Calles, J., Ferreira, V., Canhoto, C. M., \& Graça, M. (2010). Riparian land use and the relationship between the benthos and litter decomposition in tropical montane streams. Freshwater Biology, 55, 1719-1733.

Gessner, M. O., Chauvet, E., \& Dobson, M. (1999). A perspective on leaf litter breakdown in streams. Oikos, 85: 377-384.

Grau, H. R., Aide, T. M., Zimmerman, J. K., Thomlinson, J. R., Helmer, E., \& Zou, X. (2003). The ecological consequences of socioeconomic and land-use 
changes in postagriculture Puerto Rico. BioScience, 53, 1159-1168.

Greathouse E. A., Pringle, C. M., McDowell, W. H., \& Holmquist, J. G. (2006). Indirect upstream effects of dams: Consequences of migratory consumer extirpation in Puerto Rico. Ecological Applications, 16, 339-352.

Hieber, M., \& Gessner, M. O. (2002). Contribution of stream detritivores, fungi, and bacteria to leaf breakdown based on biomass estimates. Ecology, 83, 1026-1038

Holmquist, J. G., Schmidt-Gengenbach, J. M., \& Yoshioka, B. B. (1998). High dams and marine-freshwater linkages: effects on native and introduced fauna in the Caribbean. Conservation Biology, 12, 621-630.

Huryn, A. D., Butz Huryn, V. M., Arbuckle, C. J., \& Tsomides, L. (2002). Catchment land-use, macroinvertebrates and detritus processing in headwater streams: Taxonomic richness versus function. Freshwater Biology, 47, 401-415.

Hynes, J. D. (1975). Downstream drift of invertebrates in a river in southern Ghana. Freshwater Biology, 5, 515-532.

Kwak, T. J., Cooney, P. B., \& Brown, C. H. (2007). Fishery population and habitat assessment in Puerto Rico streams: phase 1 final report. San Juan: Federal Aid in Sport Fish Restauration, Final Report, Submitted to the Department of Natural and Environmental Resources.

March, J. G., Benstead, J. P., Pringle, C. M., \& Ruebel, M. W. (2001). Linking shrimp assemblages with rates of detrital processing along an elevational gradient in a tropical stream. Canadian Journal of Fisheries and Aquatic Sciences, 58, 470-478.

March, J. G., Benstead, J. P., Pringle, C. M., \& Scatena, F. N. (2003). Damming tropical island streams: Problems, solutions, and alternatives. BioScience, 53, 1069-1078.

Martinuzzi, S., Gould, W. A., \& Ramos González, O. M. (2007). Land development, land use, and urban sprawl in Puerto Rico integrating remote sensing and population census data. Landscape and Urban Planning, 79, 288-297.

McCune, B., \& Mefford, M. J. (1999). PC-ORD. Multivariate Analysis of Ecological Data, Version 4. MjM Software Design, Gleneden Beach, Oregon, USA.

Montgomery, M. R. (2008). The Urban Transformation of the Developing World. Science, 319, 761-764.

Paul, M. J., \& Meyer, J. L. (2001). Streams in the urban landscape. Annual Review of Ecology, Evolution, and Systematics, 32, 333-365.

Paul, M. J., Meyer, J. L., \& Couch, C. A. (2006). Leaf breakdown in streams differing in catchment land use. Freshwater Biology, 51, 1684-1695.
Peterson, R. C., \& Cummins, K. W. (1974). Leaf processing in a woodland stream. Freshwater Biology, 4, 343-368.

Pringle, C. M., Hemphill, N. H., McDowell, W. H., Bednarek, A., \& March, J.G. (1999). Linking species and ecosystems: different biotic assemblages cause interstream differences in organic matter. Ecology, 80, 1860-1872.

Ramírez, A., \& C.M. Pringle. (1998). Structure and production of a benthic insect assemblage in a neotropical stream. Journal of the North American Benthological Society, 17, 443-463.

Ramírez, A., Paaby, P., Pringle, C. M., \& Agüero, G. (1998). Effect of habitat type on benthic macroinvertebrates in two lowland tropical streams, Costa Rica. Revista de Biología Tropical, 46, 201-213.

Ramírez, A., \& Hernández-Cruz, L. R. (2004). Aquatic insect assemblages in shrimp-dominated tropical streams, Puerto Rico. Biotropica, 36, 259-266.

Ramírez, A., \& Pringle, C. M. (2006). Fast growth and turnover of chironomid assemblages in response to stream phosphorus levels in a tropical lowland landscape. Limnology \& Oceanography, 51, 189-196.

Ramírez, A., Pringle, C. M., \& Wantzen, K. M. (2008). Tropical River Conservation. In D. Dudgeon (Ed.). Tropical Stream Ecology (pp. 285-304). San Diego: Academic Press.

Richardson, J. S., Zhang, Y., \& Marczak, L. B. (2010). Resource subsidies across the land-freshwater interface and responses in recipient communities. River Research and Applications, 26, 55-66.

Robinson, C. T., \& Gessner, M. O. (2000). Nutrient addition accelerates leaf breakdown in an alpine springbrook. Oecologia, 122, 258-263.

Rosemond, A. D., Pringle, C. M., Ramírez, A., \& Paul, M. J. (2001). A test of top-down and bottom-up control in a detritus-based food web. Ecology, 82, 2279-2293.

Silva-Junior, E. F., Moulton, T. P., Boëchat, I. G., \& Gücker, B. (2014). Leaf decomposition and ecosystem metabolism as functional indicators of land use impacts on tropical streams. Ecological Indicators, 36, 195-204.

Sponseller, R. A., Benfield, E. F., \& Valett, H. M. (2001). Relationships between land use, spatial scale and stream macroinvertebrate communities. Freshwater Biology, 46, 1409-1424.

Suberkropp, K., \& Chauvet, E. (1995). Regulation of leaf breakdown by fungi in streams - influences of water chemistry. Ecology, 76, 1433-1445.

Suga, C. M., \& Tanaka, M. O. (2013). Influence of a forest remnant on macroinvertebrate communities in a degraded tropical stream. Hydrobiologia, 703, 2013-213. 
Sweeney, B. W., Bott, T. L., Jackson, J. K., Kaplan, L. A., Newbold, J. D., Standley, L. J., Hession, W. C., \& Horwitz, R. J. (2004). Riparian deforestation, stream narrowing, and loss of stream ecosystem services. Proceedings of the National Academy of Sciences, 101, 14132-14137.

USDA (US DEPARTMENT OF AGRICULTURE). (2001). Hawaii stream visual assessment protocol. Version 1.0. Natural Resource Conservation Service, US Department of Agriculture, Washington, DC.

Wallace, J. B., \& Gurtz, M. E. (1986). Response of baetis mayflies (Ephemeroptera) to catchment logging. American Midland Naturalist, 115, 25-41.

Wallace, J. B., Eggert, S. L., Meyer, J. L., \& Webster, J. R. (1997). Multiple trophic levels of a forest stream linked to terrestrial litter inputs. Science, 277, 102-104.

Walsh, C. J., Roy, A. H., Feminella, J. W., Cottingham, P. D., Groffman, P. M., \& Morgan, R. P. (2005). The urban stream syndrome: current knowledge and the search for a cure. Journal of the North American Benthological Society, 24, 706-723.

Webster, J. R., \& Benfield, E. F. (1986). Vascular plant breakdown in freshwater ecosystems. Annual Review of Ecology, Evolution, and Systematics, 17, 567-594.

Webster, J. R., Benfield, E.F., Ehrman, T. P., Schaeffer, M. A., Tank, J. L., Hutchens, J. J., \& D’Angelo, D. J. (1999). What happens to allochthonous material that falls into streams? A synthesis of new and published information from Coweeta. Freshwater Biology, 41, 687-705.

Wright, M. S., \& Covich, A. P. (2005). The effect of macroinvertebrate exclusion on leaf breakdown rates in a tropical headwater stream. Biotropica, 37, 403-408.

Young, R. G., Matthaei, C. D., \& Townsend, C. R. (2008). Organic matter breakdown and ecosystem metabolism: functional indicators for assessing river ecosystem health. Journal of the North American Benthological Society, 27: 605-625. 